\title{
Characterisation of the p53 pathway in cell lines established from TH-MYCN transgenic mouse tumours
}

\author{
LINDI CHEN $^{1}$, ARMAN ESFANDIARI ${ }^{2}$, WILLIAM REAVES ${ }^{1}$, ANNETTE VU $^{3}$, MICHAEL D. HOGARTY $^{3}$, \\ JOHN LUNEC $^{2}$ and DEBORAH A. TWEDDLE ${ }^{1}$ \\ ${ }^{1}$ Wolfson Childhood Cancer Research Centre and ${ }^{2}$ Newcastle Cancer Centre, Northern Institute for Cancer Research, \\ Newcastle University, Newcastle upon Tyne NE1 7RU, UK; ${ }^{3}$ The Children's Hospital of Philadelphia, \\ University of Pennsylvania Perelman School of Medicine, Philadelphia, PA 19104, USA
}

Received August 17, 2017; Accepted December 12, 2017

DOI: 10.3892/ijo.2018.4261

\begin{abstract}
Cell lines established from the TH-MYCN transgenic murine model of neuroblastoma are a valuable preclinical, immunocompetent, syngeneic model of neuroblastoma, for which knowledge of their p53 pathway status is important. In this study, the Trp53 status and functional response to Nutlin-3 and ionising radiation (IR) were determined in 6 adherent TH-MYCN transgenic cell lines using Sanger sequencing, western blot analysis and flow cytometry. Sensitivity to structurally diverse MDM2 inhibitors (Nutlin-3, MI-63, RG7388 and NDD0005) was determined using XTT proliferation assays. In total, $2 / 6$ cell lines were Trp53 homozygous mutant (NHO2A and $844^{M Y C N+/+}$ ) and $1 / 6\left(282^{M Y C N+/}\right)$ was $\operatorname{Trp} 53$ heterozygous mutant. For $1 / 6$ cell lines (NHO2A), DNA from the corresponding primary tumour was found to be Trp53 wt. In all cases, the presence of a mutation was consistent with aberrant p53 signalling in response to Nutlin-3 and IR. In comparison to TP53 wt human neuroblastoma cells, Trp53 wt murine control and TH-MYCN cell lines were significantly less sensitive to growth inhibition mediated by MI-63 and RG7388. These murine Trp53 wt and mutant TH-MYCN cell lines are useful syngeneic, immunocompetent neuroblastoma models, the former to test p53-dependent therapies in combination with immunotherapies, such as anti-GD $\mathrm{GD}_{2}$, and the latter as models of chemoresistant relapsed neuroblastoma when aberrations in the p53 pathway are more common. The spontaneous development of Trp53 mutations in 3 cell lines from TH-MYCN mice may have arisen from $M Y C N$ oncogenic driven and/or
\end{abstract}

Correspondence to: Professor Deborah A. Tweddle, Wolfson Childhood Cancer Research Centre, Northern Institute for Cancer Research, Newcastle University, Level 6 Herschel Building, Brewery Lane, Newcastle upon Tyne, NE1 7RU, UK

E-mail: deborah.tweddle@ncl.ac.uk

Abbreviations: IR, ionising radiation; wt, wild-type; PBS, phosphatebuffered saline; FCS, fetal calf serum

Key words: neuroblastoma, TH-MYCN, p53 pathway, MDM2 inhibitors, Nutlin-3, RG7388, MI-63, NDD0005 ex vivo selection. The identified species-dependent selectivity of MI-63 and RG7388 should be considered when interpreting in vivo toxicity studies of MDM2 inhibitors.

\section{Introduction}

Neuroblastoma, an embryonal malignancy of the developing sympathetic nervous system, remains one of the most difficult paediatric cancers to cure with $<50 \%$ of high-risk patients being long-term survivors despite intensive multi-modal therapy. MYCN amplification occurs in $\sim 50 \%$ of high-risk cases, associated with rapid tumour progression and a poor prognosis (1). The role of MYCN in neuroblastoma tumourigenesis has been demonstrated by the generation of TH-MYCN transgenic mice in 1997 through the transfer of a construct incorporating human $M Y C N$ cDNA under the control of the rat tyrosine hydroxylase promoter into the nucleus of fertilised murine oocytes and subsequent integration into genomic DNA $(2,3)$. The tyrosine hydroxylase promoter leads to tissue-targeted overexpression of human MYCN in neural crest cells, and mice develop spontaneous highly penetrant abdominal and para-spinal thoracic tumours consistent with sites of human neuroblastoma (2). Tumour penetrance and growth have been shown to be related to $M Y C N$ gene dosage where homozygotes develop tumours with increased incidence and decreased latency $(2,4)$. Analysis of TH-MYCN tumours has shown that they recapitulate many histological features of human neuroblastoma with varying degrees of neuronal differentiation and express synaptophysin and neuron-specific enolase (2). Moreover, tumours also exhibit chromosomal changes syntenic with those observed in human neuroblastoma tumours, such as gain of chromosome $17(2,4)$. The TH-MYCN transgenic mouse is now a well-established model of neuroblastoma, and a panel of homozygous and hemizygous TH-MYCN cell lines have been derived from tumour resections from these mice, similarly reflecting both the genetic and biological features of human neuroblastoma (5). Although micrometastases can occur, one major limitation of the TH-MYCN transgenic model in preclinical drug development studies is the very low incidence of clinically relevant metastases to sites such as bone marrow, thus limiting its usefulness as a model for high-risk metastatic neuroblastoma (6). To overcome this, TH-MYCN cell lines 
have been used to generate highly valuable orthotopic and pseudometastatic syngeneic models of neuroblastoma in an immunocompetent background $(7,8)$. This is of particular importance as immunotherapies, such as anti-GD $\mathrm{G}_{2}$ antibody are currently standard of care for the treatment of children with high-risk neuroblastoma.

The tumour suppressor gene, TP53, is critical in maintaining genomic stability and is mutationally inactivated in $>50 \%$ of all human malignancies (9). Abnormalities in the p53 pathway can contribute to tumour resistance against ionising radiation (IR) and cytotoxic chemotherapies (10-13). In neuroblastoma tumours and cell lines established at diagnosis, TP53 mutations are rare; however an increased frequency of mutations has been reported at relapse/postchemotherapy (14-16). Knowledge of Trp53 genetic and functional status in TH-MYCN cell lines is important if they are to be used in preclinical syngeneic neuroblastoma models.

In this study, we characterised the genetic and functional status of p53 in 6 adherent TH-MYCN transgenic murine cell lines, and demonstrate that $3 / 6$ cell lines have Trp53 mutations and could be used to generate valuable syngeneic models of p53 non-functional relapsed neuroblastoma. Moreover, we provide evidence of the species-dependent selectivity of some MDM2 inhibitors, which should be considered when selecting murine models for preclinical toxicity testing of MDM2 inhibitors.

\section{Materials and methods}

Cell lines. The TH-MYCN transgenic murine cell lines used were MYCN homozygous NHO2A, 844 $4^{M C N+/+}, 3261^{M Y C N+/+}$, $3394^{M Y C N+/+}, 3399^{M Y C N+/+}$ and hemizygous $282^{M Y C N+/-}$. The NHO2A cell line has been previously described (5) and together with NHO2A mouse tumour DNA, was obtained from Professor Michelle Haber (Children's Cancer Institute, Sydney, NSW, Australia). All other previously unreported TH-MYCN cell lines were established from the TH-MYCN colony at the Children's Hospital of Philadelphia (Philadelphia, PA, USA) under an IACUC approved animal protocol. Genetically-engineered $129 \mathrm{X} 1 / \mathrm{SvJ}$ mice carrying the TH-MYCN transgene in one concatamer (TH- $M Y C N^{+/}$mice) or two concatamers (TH-MYCN ${ }^{+/+}$mice) develop tumours closely resembling human neuroblastoma (2). TH- $M Y C N^{+/}$ mice were bred and offspring genotyped as described previously (17). TH-MYCN mice were euthanised at the time of tumour progression according to humane approved guidelines using 3-5\% isoflurane inhalation followed by cervical dislocation. The mice were then disinfected with $70 \%$ ethanol prior to resecting the tumour free. Tumours were fragmented and filtered through a $40 \mu \mathrm{m}$ nylon mesh filter into a conical tube, spun-pelleted, and resuspended in sterile Tris Ammonia Chloride buffer, buffered to $\mathrm{pH}$ 7.65. Tumour cell pellets were incubated at $37^{\circ} \mathrm{C}$ for $5 \mathrm{~min}$, rinsed and spun-pelleted multiple times in phosphate-buffered saline (PBS) and then plated in RPMI tissue culture media supplemented with $10 \%$ fetal calf serum (FCS), 1\% L-glutamine and 1\% penicillin/streptamycin/gentamycin. The cells were propagated under routine tissue culture conditions and $\sim 50 \%$ resulted in an established cell line over $\sim 8$ weeks. The TH-MYCN cell lines established were validated as tyrosine hydroxylase-positive by RT-PCR
(>95\% positive) and had surface expression of the $\mathrm{GD}_{2}$ disialoganglioside, as detected by flow cytometry. The control murine cell lines used were Trp53 wild-type (wt) $\mathrm{MEF}^{\text {PARP-/ }}$ obtained from Dr Gilbert de Murcia (18) and NIH3T3 cells. The control human neuroblastoma cell lines used were TP53 mutant, MYCN-amplified SK-N-BE(2)-C, and TP53 wt non- $M Y C N$-amplified SHSY5Y [obtained from Professor Penny Lovat (Newcastle University, Newcastle upon Tyne, UK) and Dr June Biedler (Memorial Sloan Kettering Cancer Center, New York, NY, USA) and authenticated by multiplex short tandem repeat profiling by NewGene Ltd. (Newcastle upon Tyne, UK) using the GenePrint ${ }^{\circledR} 10$ system] and TP53 wt $M Y C N$-amplified NGP cells (19). The NHO2A cells were cultured as previously described (5). The $844^{M Y C N+/+}, 282^{M Y C N+/-}$, SHSY5Y, SK-N-BE(2)-C and NGP cells were cultured in RPMI-1640 (Sigma-Aldrich, Irvine, UK) supplemented with $10 \%$ fetal calf serum (FCS) (Gibco, Paisley, Scotland) and the $3261^{M Y C N+/+}$, 3394 $4^{M Y N+/+}$ and $3399^{M Y C N+/+}$ cells were cultured in RPMI-1640 supplemented with $20 \% \mathrm{FCS}_{\text {. MEF }} \mathrm{MARP-/}$ and NIH3T3 cells were cultured in Dulbecco's modified Eagle's medium (Sigma-Aldrich) supplemented with $10 \%$ FCS.

Trp53 sequencing. DNA was extracted from tumours and cell lines using a DNeasy Blood and Tissue kit (Qiagen, Manchester, UK) according to the manufacturer's instructions. DNA from NHO2A, 844 $4^{M Y C+/+}$ and $282^{M Y C N+/-}$ cells was amplified for Trp53 exons 2-10 and sequenced in both directions by DBS genomics (Durham University, Durham, UK). The primer sequences are available upon request. The $3261^{M Y C N+/+}$, $3394^{M Y C N+/+}$ and $3399^{M Y C N+/+}$ DNA samples were amplified and sequenced in both directions for Trp53 exons 5-10 by LGC Genomics GmbH (Berlin, Germany).

MDM2 inhibitors, IR, western blot analysis and flow cytometry. In brief, RG7388 was provided by Hoffman-La Roche (Nutley, NJ, USA), Nutlin-3 was purchased from Cambridge Bioscience Ltd. (Cambridge, UK) and MI-63 and NDD0005 were synthesised as previously described $(20,21)$. The cells were irradiated using a RS320 irradiator (Gulmay Medical, Surrey, UK). For protein analysis, whole cell lysates were harvested and proteins separated using 4-20\% Mini-Protean TGX Precast Gels (Bio-Rad Laboratories Ltd., Hemel Hempstead, UK) and transferred onto Hybond-C Extra membrane prior to incubation with antibodies and detection using enhanced chemiluminescence (both from GE Healthcare Life Sciences, Little Chalfont, UK) and X-ray film (Fujifilm, Bedford, UK). The primary antibodies used were p53 (1:1,000; CM5; Leica Microsystems Ltd., Buckinghamshire, UK), MYCN (1:100; NCMII00; Merck Millipore, Billerica, MA, USA), p21 ${ }^{\mathrm{WAF} 1}$ (1:1,000; SX118; BD Biosciences, San Jose, CA, USA), Mdm2 1:500 (2A10), p19 ARF 1:500 (ab80) (both from Abcam, Cambridge, MA, USA) and glyceraldehyde 3-phosphate dehydrogenase (GAPDH) 1:500 (FL335; Santa Cruz Biotechnology, Inc., Dallas, TX, USA). Cell growth inhibition was determined using the XTT cell proliferation assay (Roche, Burgess Hill, UK). The cells were seeded in 96-well plates (Corning, VWR International Ltd., Lutterworth, UK), allowed to adhere overnight prior to treatment with MDM2p53 antagonists for $48 \mathrm{~h}$. For flow cytometry analysis, cells were fixed in ice-cold $70 \%(\mathrm{v} / \mathrm{v})$ ethanol, and stained with 
$50 \mu \mathrm{g} / \mathrm{ml}$ propidium iodide and $50 \mu \mathrm{g} / \mathrm{ml}$ RNAse A (both from Sigma-Aldrich) at $37^{\circ} \mathrm{C}$ for $30 \mathrm{~min}$ prior to analysis on the FACSCalibur (Becton-Dickinson, Oxford, UK). Data were analysed using Cyflogic (CyFlo Ltd., Turku, Finland).

Statistical analyses. Two-sided unpaired t-tests were performed using GraphPad Prism v6.0 software with a value of $\mathrm{P}<0.05$ considered as the level of significance.

\section{Results}

Trp53 status of TH-MYCN cell lines. All TH-MYCN transgenic cell lines used in the present study were cultured as adherent monolayers (Fig. 1A). Trp53 Sanger sequencing identified that $3 / 6$ cell lines, the $\mathrm{NHO} 2 \mathrm{~A}, 844^{M Y C N+/+}$ and $282^{M Y C N+/-}$ cells, had missense coding region point mutations (Fig. 1B-D). The NHO2A cells were homozygous for a p.F106S (phenylalanine to serine; c.317 C>T) Trp53 mutation corresponding to the human p.F109S TP53 missense mutation (Fig. 1B). The $844^{M Y C N+/+}$ cells were Trp53 homozygous mutant for a p.C173W (cysteine to tryptophan; c.519 C>G) mutation corresponding to the human p.C176W missense mutation (Fig. 1C). Of note, the $282^{M Y C N+/}$ cells were heterozygously mutated for the same Trp53 p.C173W mutant allele as the $844^{M Y C N+/+}$ cells (Fig. 1D). Both p.F106S and p.C173W mutations are within the DNA binding domain and were predicted to affect p53-mediated transactivation using the TP53Mutload database. The homozygous mutations detected in $\mathrm{NHO} 2 \mathrm{~A}$ and $844^{\mathrm{MYCN+/+}}$ cells are most likely to be due to allelic loss of one allele with mutation in the remaining allele.

To determine whether the mutations present in cell lines were also present in the original tumours or selected for during establishment of the cell line, tumour DNA was sequenced for Trp53 exons 2-10. Only 1/6 cell lines (NHO2A) had tumour DNA available and was found to be wt (Fig. 1E).

MYCN and the p53 pathway in TH-MYCN cell lines. Basal expression of MYCN and p53 pathway components, namely p53, Mdm2, p2 $1^{\mathrm{WAF} 1}$ and p19 ${ }^{\mathrm{ARF}}$ were assessed in TH-MYCN cell lines by western blot analysis (Fig. 1F). The Trp53 wt murine $\mathrm{MEF}^{P A R P-/}$ and NIH3T3, and human $M Y C N$ amplified TP53 mutant SK-N-BE(2)-C cells were included as controls. Overexpression of the $M Y C N$ transgene was observed in all TH-MYCN cell lines, with levels comparable to those of the $M Y C N$-amplified SK-N-BE(2)-C cells. NHO2A and $844^{M Y C N+/+}$ cells had the highest $M Y C N$ levels compared to the other TH-MYCN cell lines. Accumulation of p53 was observed in NHO2A, $844^{M Y C N++}$ and $282^{M Y C N+/}$ cells, consistent with their mutant Trp53 status. All mouse cell lines had very low or undetectable baseline Mdm2 expression (Fig. 1F). p21 ${ }^{\text {WAF1 }}$ was expressed only in Trp53 wt $3399^{M Y C N+/+}$ cell line (Fig. 1F). p19 ${ }^{\mathrm{ARF}}$ was expressed in NHO2A, $844^{M Y C N+/+}, 3394^{M Y C N+/+}$ and $3399^{M Y C N+/+}$ cells (Fig. 1F).

The response of the p53 pathway to Nutlin-3 and IR. Using Nutlin-3 and IR as different methods to induce p53 activation, activation of the p53 signalling pathway was assessed by western blot analysis in the TH-MYCN cell lines and control Trp53 wt MEF ${ }^{P A R P-/-}$ cells (Figs. 2 and 3). Consistent with their Trp53 wt status, $\mathrm{MEF}^{\text {PARP-/ }}$ cells exhibited an intact p53 signalling pathway in response to both Nutlin-3 and IR, evident by $\mathrm{p} 53$ stabilisation and $\mathrm{Mdm} 2$ and $\mathrm{p} 21^{\mathrm{WAF} 1}$ upregulation (Figs. 2A and 3A). Of note, the p53 pathway response of MEF $^{\text {PARP-/ }}$ cells to IR was slightly diminished and delayed in comparison to Nutlin-3 (Figs. 2A and 3A), and is most likely a consequence of PARP-1 knockout in this cell line (22). As expected, homozygously Trp53 mutant NHO2A and $844^{M Y C N++}$ cells failed to show p53 induction in response to Nutlin-3 (Fig. 2B and C) or IR (Fig. 3B and C). Consistent with this observation, no $\mathrm{p} 21^{\mathrm{WAF} 1}$ induction was observed in either cell line, and no Mdm2 induction was observed in $844^{M Y C N+/+}$ cells. Of note, despite a lack of p53 induction, weak induction of Mdm2 was observed in NHO2A cells following both treatment with Nutlin-3 and exposure to IR (Figs. 2B and 3B). The heterozygously Trp53 mutant $282^{M Y C N+/-}$ cells also failed to show p53 stabilisation in response to Nutlin-3 or IR; however in spite of this, an increase in both Mdm2 and p21 ${ }^{\mathrm{WAF} 1}$ expression was observed (Figs. 2D and 3D), most likely as a result of the presence of one remaining wt Trp53 allele. Finally, in line with their Trp53 wt status, the 3 remaining TH-MYCN cell lines, $3261^{M Y C N+/+}$, $3394^{M Y C N+/+}$ and $3399^{M Y C N+/+}$, all showed evidence of IR- and Nutlin-3-induced p53 pathway activation, with stabilisation of p53, and induction of p21 and Mdm2 (Figs. 2E-G and 3E-G).

Nutlin-3-induced cell cycle distribution. To further characterise the p53 functional response in the TH-MYCN cell lines to Nutlin-3, the sub- $\mathrm{G}_{1}$ and cell cycle distribution of all the 6 TH-MYCN cell lines following $24 \mathrm{~h}$ treatment with $20 \mu \mathrm{M}$ Nutlin-3 were analysed by propidium iodide-based flow cytometry. Sub- $G_{1}$ events was used as a surrogate marker of apoptosis and the $\mathrm{G}_{1}: \mathrm{S}$ ratio calculated as an indicator of $\mathrm{G}_{1}$ cell cycle arrest. Trp53 wt NIH3T3 and $\mathrm{MEF}^{\text {PARP-/ }}$ cells were included as positive controls. The functional assessment of Nutlin-3-mediated cell cycle arrest and apoptosis of human neuroblastoma cell lines have previously been reported $(23,24)$. In response to Nutlin-3 treatment, NIH3T3 cells underwent $\mathrm{G}_{1}$ arrest, evident by a 4.6 -fold increase in their $\mathrm{G} 1 / \mathrm{S}$ ratio $[16.58 \pm 4.43$ (Nutlin-3) vs. 3.61 \pm 0.17 (DMSO)] (Table I and Fig. 4A). Consistent with the observed activation of the 553 pathway in Fig. $2 \mathrm{~A}$, the $\mathrm{MEF}^{\text {PARP-/ }}$ cells demonstrated a 3.2-fold increase in their $\mathrm{G}_{1}: \mathrm{S}$ ratio $[7.19 \pm 3.32$ (Nutlin-3) vs. $2.23 \pm 0.23$ (DMSO)], and a significant increase in the percentage of cells in $\mathrm{G}_{2} / \mathrm{M}$ phase $[53.32 \% \pm 4.19$ (Nutlin-3) vs. $34.75 \% \pm 1.63$ (DMSO); $\mathrm{P}<0.005$, paired t-test] (Table I and Fig. 4A), indicative of a Nutlin-3-induced $G_{1}$ and particularly $\mathrm{G}_{2}$ arrest in this cell line. In contrast to control Trp53 wt murine cell lines, and as expected, no noticeable changes in the $G_{1} / S$ ratio or percentage of cells in $G_{2} / M$ phase were observed in any Trp53 mutant TH-MYCN NHO2A, $844^{M Y C N+/+}$ or $282^{M Y C N+/-}$ cells (Table I and Fig. 4A). Of note, compared to the other murine cell lines, NHO2A and $282^{M Y C N+/}$ cells had a high proportion of sub- $\mathrm{G}_{1}$ basal events (Table I and Fig. 4A), a surrogate marker of apoptosis, which following Nutlin-3 treatment, increased slightly and remained unaltered, respectively. Consistent with their Trp53 wt status and observed p53 pathway activation, as shown in Fig. $2 \mathrm{E}-\mathrm{G}$, the $3 \operatorname{Trp} 53 \mathrm{wt}$ TH-MYCN cell lines, $3261^{M Y C N+/+}, 3394^{M Y C N+/+}$ and $3399^{M Y C N+/+}$, all underwent a $G_{1}$ phase arrest, as evident by a 5.2-, 5- and 3.4-fold increase in $G_{1} / S$ ratio compared to control cells, 
A

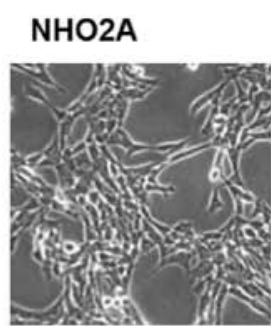

$3261^{\mathrm{MYCN}+/+}$

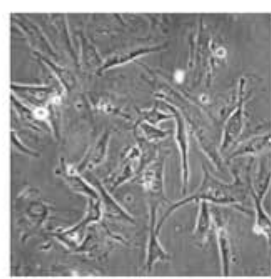

B

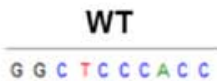

$\frac{\text { NHO2A }}{G G C T T C C A C C}$

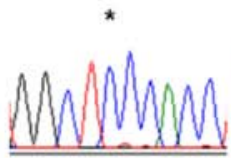

D
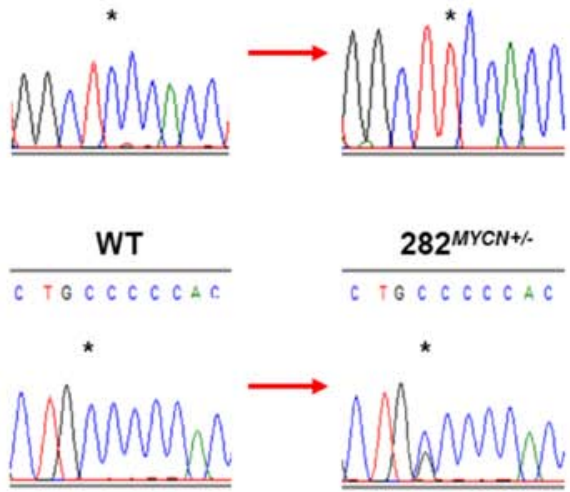

$844^{\mathrm{MrCN}+/+}$

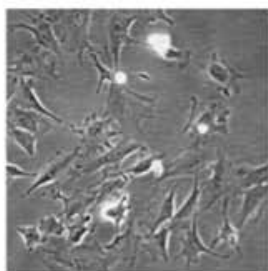

$3399 \mathrm{MYCN+1+}$
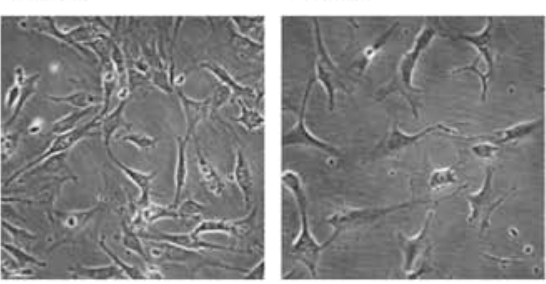

C

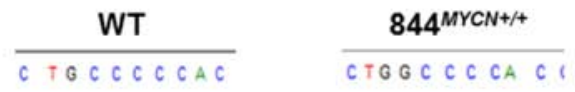

E
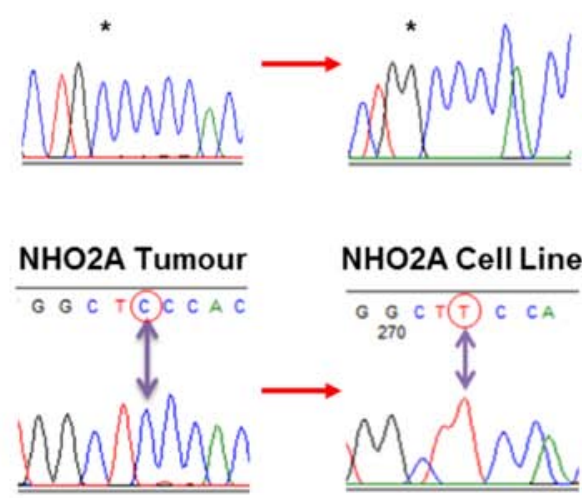

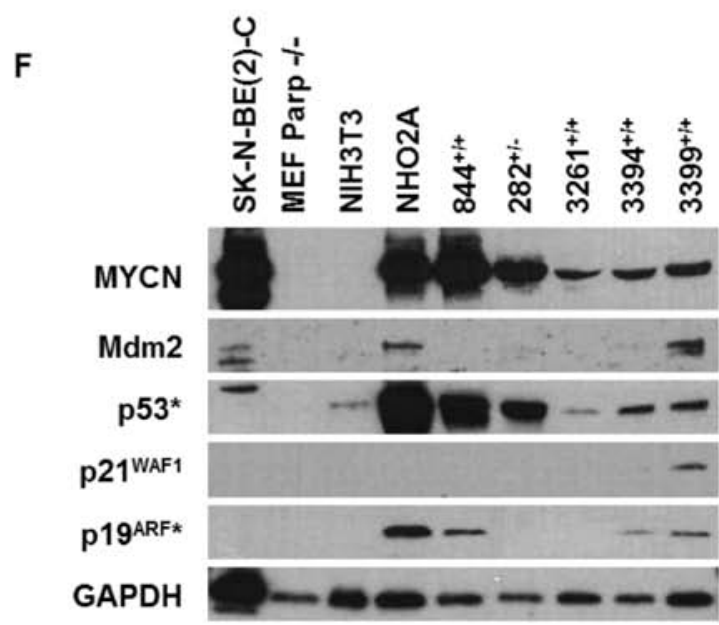

Figure 1. (A) Photomicrographs showing the morphological appearance of NHO2A, $282^{M Y C N+/-}, 844^{M Y C N+/+}, 3261^{M Y C N+/+}, 3394^{M Y C N+/+}$ and $3399^{M Y C N+/+}$ TH- $M Y C N$ murine neuroblastoma cell lines. Chromatograms showing Trp53 gene mutations identified in (B) NHO2A (homozygous mutation, codon 106, phenylalanine to serine), (C) $844^{M Y C N+/+}$ (homozygous mutation, codon 173 , cysteine to tryptophan) and (D) $282^{M Y C N+/}$ (heterozygous mutation, codon 173 , cysteine to tryptophan). All mutations are within the DNA binding domain of p53. The asterisk (*) marks the nucleotide change. (E) Chromatograms showing the Trp53 wild-type (wt) status of the original tumour from which the NHO2A cell line was derived compared to the homozygous p.F106S (c.317C $>$ T) mutation identified in the NHO2A cell line. (F) Western blot analysis of the basal expression of MYCN, Mdm2, p53, p21 ${ }^{\mathrm{WAF} 1}$ and p19 ${ }^{\mathrm{ARF}}$ (murine homologue of p14 ${ }^{\mathrm{ARF}}$ ) in the murine cell line panel in comparison to the TP53 mutant MYCN amplified SK-N-BE(2)-C human neuroblastoma cell line. ${ }^{*}$ p53 and p19.RF antibodies are only reactive against murine $\mathrm{p} 53$ and $\mathrm{p} 19^{\mathrm{ARF}}$.

respectively (Table I and Fig. 4A). In addition, the $3399^{M Y C N+/+}$ cells also exhibited an increased sub- $\mathrm{G}_{1}$ population (Table I and Fig. 4A).
Species-dependent MDM2 inhibitor selectivity. MDM2 inhibitors are currently under preclinical and clinical evaluation as a novel therapeutic for neuroblastoma. To further evaluate 
A MEFPARP-1-
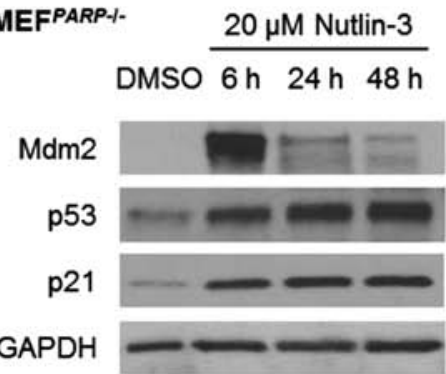

\section{B NHO2A}

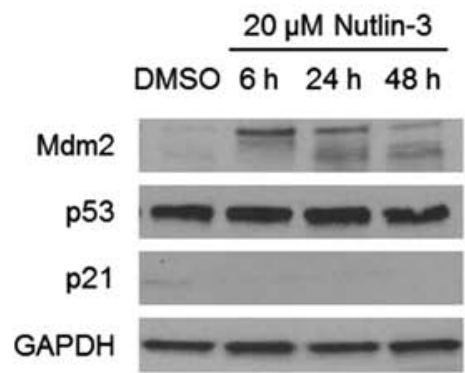

D $282^{\text {MYCN+1- }}$

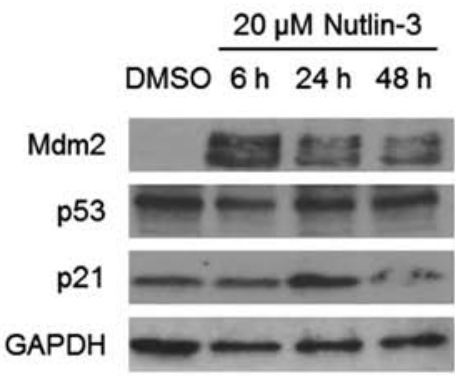

F $3394^{M Y C N+1+}$

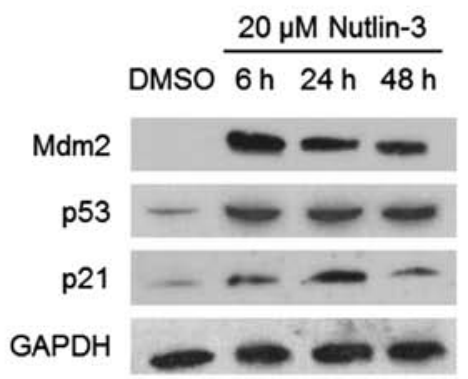

C $844^{\mathrm{MYCN}+1+}$

\section{DMSO $\frac{20 \mu \mathrm{M} \text { Nutlin-3 }}{6 \mathrm{~h} \quad 24 \mathrm{~h} 48 \mathrm{~h}}$}

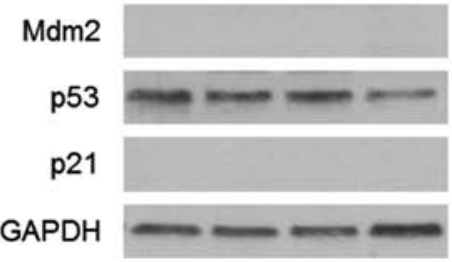

E $3261^{M Y C N+1+}$

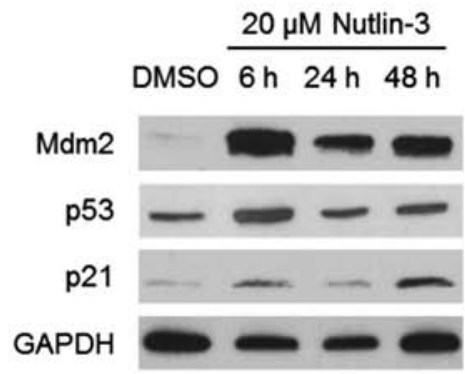

G $3399^{M Y C N+1+}$

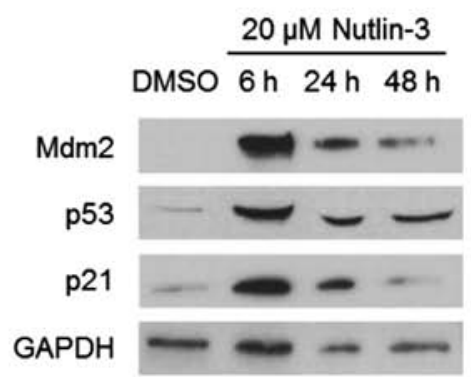

Figure 2. The response of the 53 pathway of the MEF ${ }^{\text {PARP-l }}$ and TH-MYCN transgenic murine cell lines to the MDM2 inhibitor, Nutlin-3. Western blot analysis showing levels of $\mathrm{p} 53$ and $\mathrm{p} 53$ target genes, Mdm2 and p21 $1^{\mathrm{WAF}}$ in (A) MEF $\mathrm{MARP-/}^{P}$, (B) NHO2A, (C) $844^{M Y C N+/+}$, (D) $282^{M Y C N+/}$, (E) $3261^{M Y C N+/+}$, (F) $3394^{M Y C N+/+}$ and $(\mathrm{G}) 3399^{M Y C N+/+}$ cells after 6,24 and $48 \mathrm{~h}$ of treatment with $20 \mu \mathrm{M}$ Nutlin-3. Control cells were treated with either media alone (M) or media containing an equal volume of DMSO (DMSO).

the p53 pathway status of cell lines studied and establish their response to MDM2 inhibitors, sensitivity to Nutlin-3 and additional structurally unrelated MDM2 inhibitors, NDD0005, MI-63 and RG7388, and their effects on growth inhibition were assessed (Table II). Human TP53 wt non-MYCN amplified SHSY5Y and MYCN amplified NGP cells, which have previously been shown to be sensitive to the tested MDM2 inhibitors $(20,21,23)$, were included as positive controls. The concentrations of Nutlin-3, MI63, NDD0005 and RG7388, which led to a $50 \%$ growth inhibition $\left(\mathrm{GI}_{50}\right)$ after $48 \mathrm{~h}$ of treatment, are shown in Table II. In comparison to TP53 wt human neuroblastoma cells, the Trp53 wt control and TH-MYCN murine cell lines were less sensitive to Nutlin-3-mediated growth inhibition, as evidenced by higher $\mathrm{GI}_{50}$ concentrations 
A MEFPARP-\%.

$$
\text { M } \frac{10 \text { Gy IR }}{6 h 24 h 48 h}
$$

Mdm2

p53

p21

GAPDH

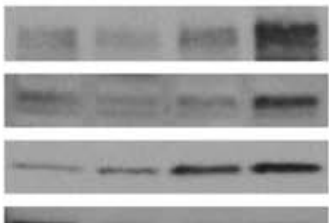

B NHO2A

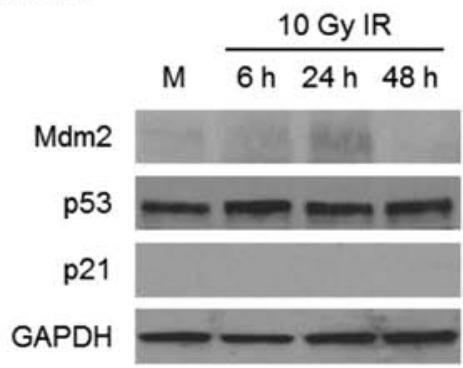

D $282^{\text {MYCN+1- }}$

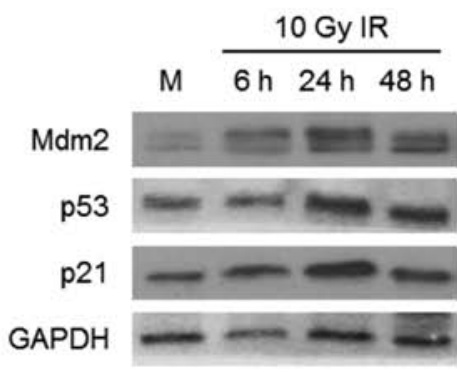

F $3394^{M Y C N+1+}$

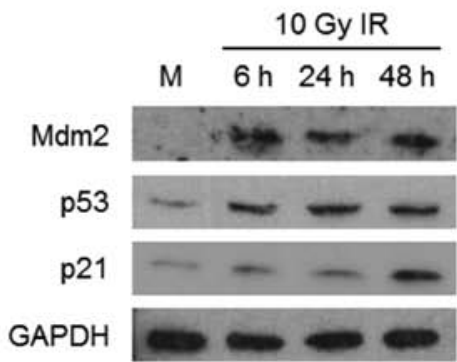

C $844^{\mathrm{MYCN}+1+}$

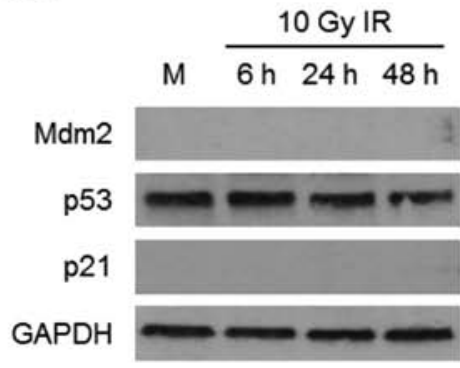

E $3261^{M Y C N+/+}$

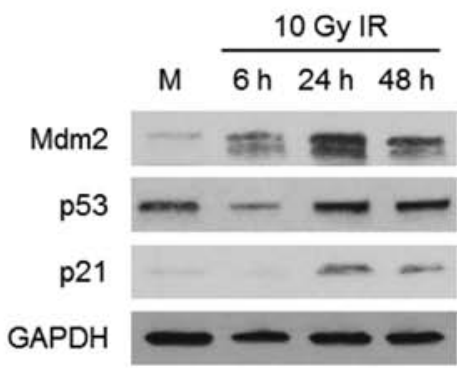

G $3399^{M Y C N+1+}$

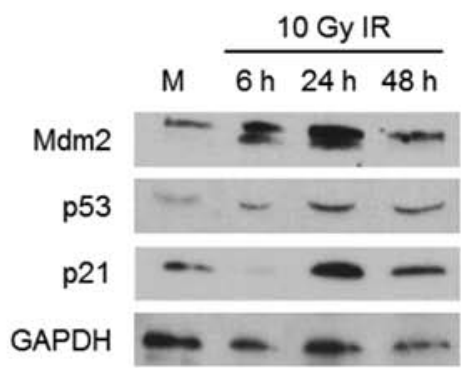

Figure 3. The p53 pathway response of $\mathrm{MEF}^{\text {PARP-/ }}$ and TH-MYCN transgenic murine cell lines to ionising radiation (IR)-induced DNA damage. Western blot analysis showing the levels of p53 and p53 target genes, Mdm2 in (A) $\mathrm{MEF}^{P A R P-/}$, (B) NHO2A, (C) $844^{M Y C N+/+}$, (D) $282^{M Y C N+/}$, (E) $3261^{M Y C N+/+}$, (F) $3394^{M Y C N+/+}$ and (G) $3399^{M Y C N+/+}$ cells at 6,24 and $48 \mathrm{~h}$ following exposure to 10 Gy IR. Control cells received no IR (M).

(1.2-7.4-fold less sensitive) (Table II and Fig. 4B). As expected, Trp53 mutant TH-MYCN cell lines NHO2A, $844^{M Y C N+/+}$ and $282^{M Y C N+/}$ had the highest $\mathrm{GI}_{50}$ values (14.1-21.8-fold less sensitive) (Table II).

Further evaluation and comparison of Trp53 wt TH-MYCN and $\mathrm{MEF}^{\text {PARP-/ }}$ cells to NDD0005, MI-63 and RG7388, demonstrated that although the $\mathrm{MEF}^{P A R P-/}$ cells were significantly (2.5-3.6-fold) less sensitive to NDD0005, there was no difference in the sensitivity of Trp53 wt TH-MYCN cell lines to NDD0005 compared with human SHSY5Y and NGP neuroblastoma cells (Table II and Fig. 4C). Of the tested MDM2 inhibitors, MI-63 and RG7388 were the most potent against human neuroblastoma cell lines, consistent with the findings of our previous studies $(20,23)$. The data also revealed that

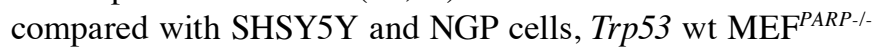
cells were significantly (11.3-15.4- and 11.9-15.0-fold) less 
A

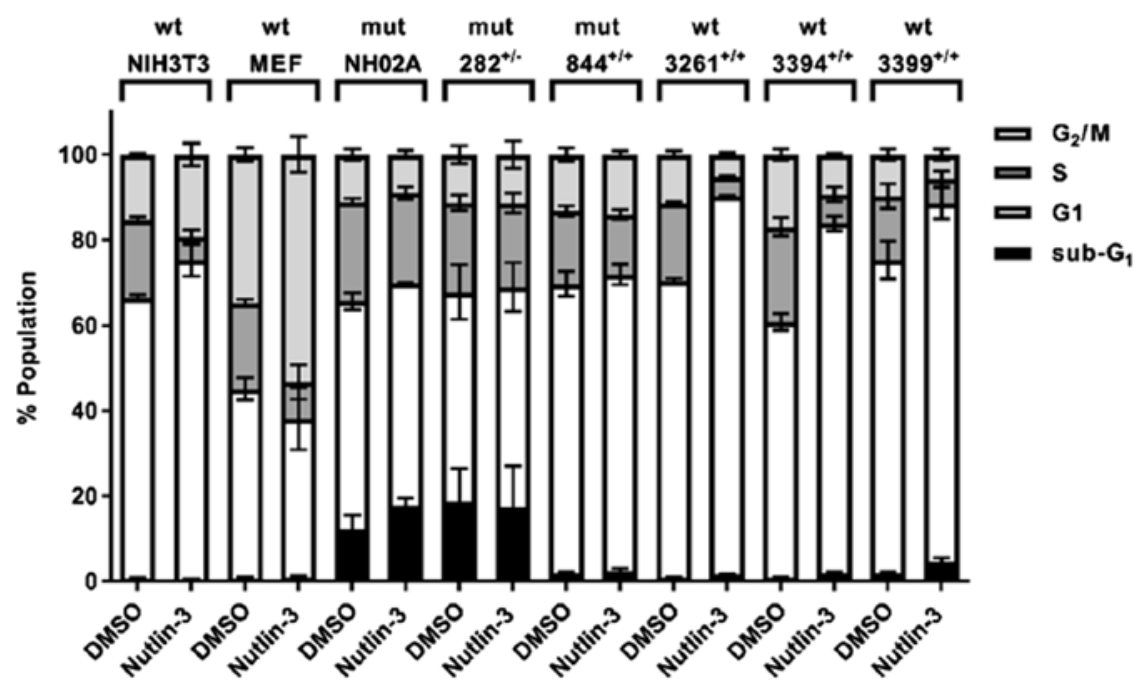

B

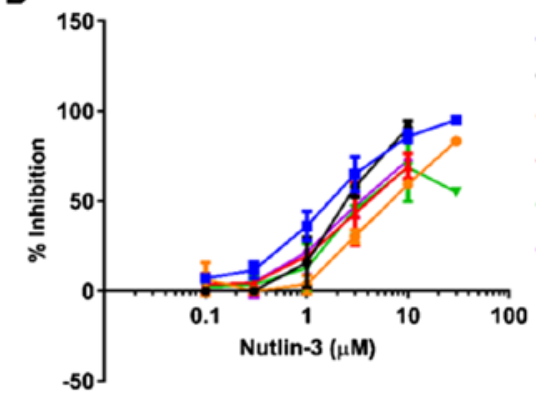

D

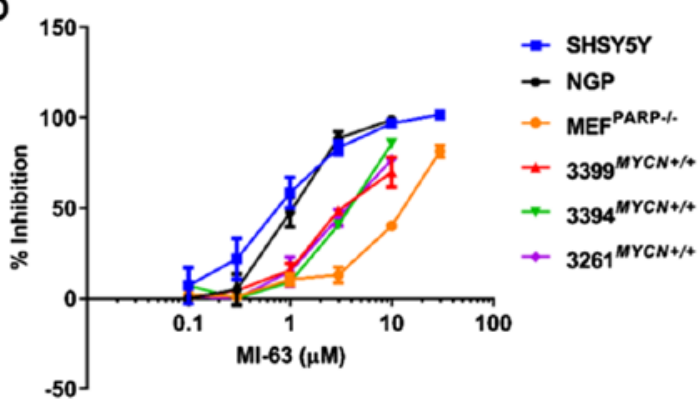

C

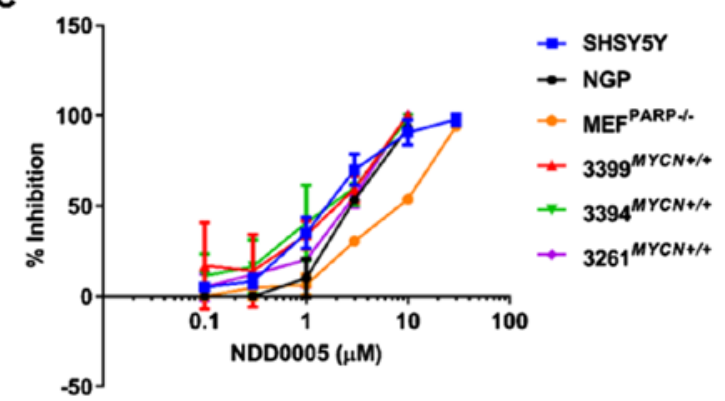

E

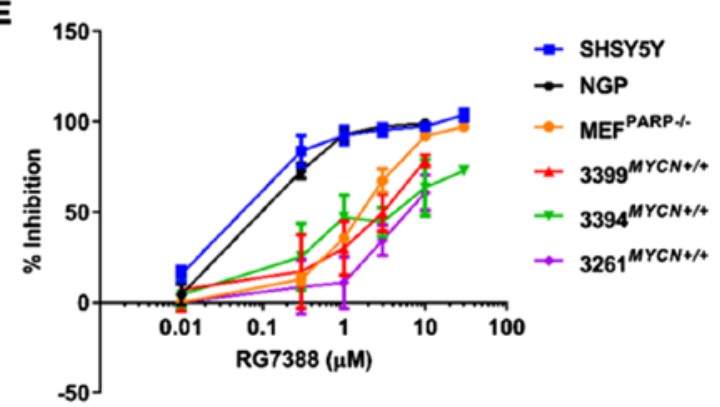

Figure 4. Cell cycle distribution and sensitivity of murine cell lines in response to Nutlin-3. (A) Graph showing the cell cycle distribution of $\operatorname{Trp} 53$ wild-type (wt) murine control cells NIH3T3 and MEF ${ }^{P_{A R P}-/}$, and the $6 \mathrm{TH}-M Y C N$ cell lines after $24 \mathrm{~h}$ of treatment with $20 \mu \mathrm{M}$ Nutlin-3. Control cells were treated with media containing an equal volume of DMSO (DMSO). Error bars represent the SEM for $\mathrm{n}=3$ repeat experiments. wt, $\operatorname{Trp} 53 \mathrm{wt}$; mut, $\operatorname{Trp} 53$ mutant.

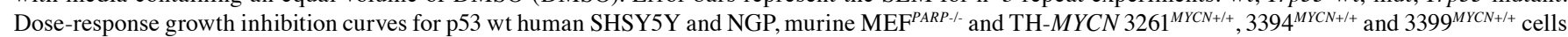
in response to $48 \mathrm{~h}$ treatment with (B) Nutlin-3, (C) NDD0005, (D) MI-63 and (E) RG7388.

sensitive to both MI-63 and RG7388, respectively (Table II and Fig. 4D and E). Furthermore, the data also indicated that Trp53 wt TH-MYCN cell lines were significantly (3.5-5.1-fold) less sensitive to MI-63 (Table II and Fig. 4D), and even less so (13.6-59.1-fold) to RG7388 (Table II and Fig. 4E). This highlights an inverse association between potency in TP53 wt human neuroblastoma cells and potency in $\operatorname{Trp} 53 \mathrm{wt}$ murine cells.

\section{Discussion}

Cell lines established from primary tumours resected from TH-MYCN mice have been used to develop valuable preclinical immunocompetent, syngeneic models of neuroblastoma $(7,8)$, for which knowledge of their p53 pathway status is important. In this study, we demonstrated that $2 / 6 \mathrm{TH}-M Y C N$ cell lines were $\operatorname{Trp} 53$ homozygous mutant $\left(\mathrm{NHO} 2 \mathrm{~A}\right.$ and $844^{M Y C N+/+}$ ) and $1 / 6$ was heterozygous mutant $\left(282^{M Y C N+/}\right)$. In the only case where DNA from the original tumour was available (NHO2A), the original tumour was Trp53 wt. This is consistent with our previous analysis of 13 primary TH-MYCN tumours, which did not show any Trp53 mutations (exons 4-8) (25). It is possible that $\operatorname{Trp} 53$ mutant subpopulations existed within the primary tumour, but were below the level of detection of Sanger sequencing, or that the mutation spontaneously developed and was selected for during ex vivo culturing pressures and cell line establishment. A $M Y C N$ oncogenic drive may be a strong contributing factor for the positive selection of Trp53 mutations 
Table I. Flow cytometric analysis of the proportion of cells in Sub- $G_{1}, G_{1}, S$, and $G_{2} / M$ phase, and the $G_{1} / S$ ratios in the panel cell lines used in this study.

$\%$ Cell population in each phase

\begin{tabular}{|c|c|c|c|c|c|c|}
\hline $\begin{array}{l}\text { Cell line and } \\
\text { Trp53 status }\end{array}$ & $\begin{array}{l}\text { Treatment } \\
\text { condition }\end{array}$ & Sub-G $G_{1}$ & $\mathrm{G}_{1}$ & $\mathrm{~S}$ & $\mathrm{G}_{2} / \mathrm{M}$ & $\mathrm{G}_{1} / \mathrm{S}$ ratio \\
\hline $\begin{array}{l}\mathrm{MEF}^{\text {PARP-/ }} \\
(\mathrm{wt})\end{array}$ & $\begin{array}{l}\text { DMSO } \\
\text { Nutlin-3 }\end{array}$ & $\begin{array}{l}0.66 \pm 0.37 \\
0.86 \pm 0.31\end{array}$ & $\begin{array}{l}44.46 \pm 2.57 \\
37.29 \pm 7.29\end{array}$ & $\begin{array}{r}20.13 \pm 0.89 \\
8.52 \pm 4.03\end{array}$ & $\begin{array}{l}34.75 \pm 1.63 \\
53.32 \pm 4.19\end{array}$ & $\begin{array}{l}2.23 \pm 0.23 \\
7.19 \pm 3.32\end{array}$ \\
\hline $\begin{array}{l}\text { NIH3T3 } \\
(w t)\end{array}$ & $\begin{array}{l}\text { DMSO } \\
\text { Nutlin-3 }\end{array}$ & $\begin{array}{l}0.58 \pm 0.28 \\
0.39 \pm 0.17\end{array}$ & $\begin{array}{l}65.84 \pm 0.7 \\
74.89 \pm 3.73\end{array}$ & $\begin{array}{r}18.31 \pm 0.70 \\
5.37 \pm 1.64\end{array}$ & $\begin{array}{l}15.27 \pm 0.26 \\
19.34 \pm 2.68\end{array}$ & $\begin{array}{r}3.61 \pm 0.17 \\
16.58 \pm 4.43\end{array}$ \\
\hline $\begin{array}{l}\mathrm{NHO} 2 \mathrm{~A} \\
\text { (mutant) }\end{array}$ & $\begin{array}{l}\text { DMSO } \\
\text { Nutlin-3 }\end{array}$ & $\begin{array}{l}12.29 \pm 3.2 \\
17.76 \pm 1.68\end{array}$ & $\begin{array}{l}53.35 \pm 1.98 \\
52.06 \pm 0.23\end{array}$ & $\begin{array}{l}23.28 \pm 0.79 \\
21.14 \pm 1.44\end{array}$ & $\begin{array}{r}11.07 \pm 1.33 \\
9.04 \pm 0.94\end{array}$ & $\begin{array}{l}2.29 \pm 0.01 \\
2.48 \pm 0.15\end{array}$ \\
\hline $\begin{array}{l}282^{M Y C N+/-} \\
\text { (mutant) }\end{array}$ & $\begin{array}{l}\text { DMSO } \\
\text { Nutlin-3 }\end{array}$ & $\begin{array}{l}18.60 \pm 7.73 \\
17.37 \pm 9.66\end{array}$ & $\begin{array}{l}49.16 \pm 6.4 \\
51.58 \pm 5.73\end{array}$ & $\begin{array}{l}20.95 \pm 1.81 \\
19.69 \pm 2.29\end{array}$ & $\begin{array}{l}11.28 \pm 2.12 \\
11.37 \pm 3.22\end{array}$ & $\begin{array}{r}2.4 \pm 0.41 \\
2.68 \pm 0.41\end{array}$ \\
\hline $\begin{array}{l}844^{M Y C N+/+} \\
\text { (mutant) }\end{array}$ & $\begin{array}{l}\text { DMSO } \\
\text { Nutlin-3 }\end{array}$ & $\begin{array}{l}1.91 \pm 0.23 \\
2.44 \pm 0.58\end{array}$ & $\begin{array}{l}67.80 \pm 2.88 \\
69.50 \pm 2.4\end{array}$ & $\begin{array}{l}17.09 \pm 1.16 \\
13.96 \pm 1.20\end{array}$ & $\begin{array}{l}13.18 \pm 1.59 \\
14.10 \pm 0.92\end{array}$ & $\begin{array}{l}4.03 \pm 0.45 \\
5.09 \pm 0.64\end{array}$ \\
\hline $\begin{array}{l}3261^{M Y C N+/+} \\
(\mathrm{wt})\end{array}$ & $\begin{array}{l}\text { DMSO } \\
\text { Nutlin-3 }\end{array}$ & $\begin{array}{l}0.86 \pm 0.09 \\
1.58 \pm 0.05\end{array}$ & $\begin{array}{l}69.45 \pm 0.65 \\
88.61 \pm 0.28\end{array}$ & $\begin{array}{r}18.28 \pm 0.32 \\
4.57 \pm 0.41\end{array}$ & $\begin{array}{r}11.40 \pm 0.87 \\
5.24 \pm 0.41\end{array}$ & $\begin{array}{r}3.8 \pm 0.03 \\
19.67 \pm 1.68\end{array}$ \\
\hline $\begin{array}{l}3394^{M Y C N+/+} \\
\text { (wt) }\end{array}$ & $\begin{array}{l}\text { DMSO } \\
\text { Nutlin-3 }\end{array}$ & $\begin{array}{l}0.91 \pm 0.16 \\
1.86 \pm 0.36\end{array}$ & $\begin{array}{l}59.88 \pm 1.98 \\
82.01 \pm 1.72\end{array}$ & $\begin{array}{r}22.28 \pm 2.12 \\
6.82 \pm 1.68\end{array}$ & $\begin{array}{r}16.94 \pm 1.31 \\
9.31 \pm 1.39\end{array}$ & $\begin{array}{r}2.79 \pm 0.38 \\
14.03 \pm 2.82\end{array}$ \\
\hline $\begin{array}{l}3399^{M Y C N+/+} \\
(\mathrm{wt})\end{array}$ & $\begin{array}{l}\text { DMSO } \\
\text { Nutlin-3 }\end{array}$ & $\begin{array}{l}1.80 \pm 0.37 \\
4.63 \pm 0.97\end{array}$ & $\begin{array}{l}73.46 \pm 4.43 \\
83.93 \pm 3.61\end{array}$ & $\begin{array}{r}14.98 \pm 2.88 \\
5.76 \pm 1.79\end{array}$ & $\begin{array}{l}9.77 \pm 1.39 \\
5.69 \pm 1.26\end{array}$ & $\begin{array}{r}5.55 \pm 1.69 \\
18.67 \pm 7.01\end{array}$ \\
\hline
\end{tabular}

Cell cycle analysis was performed using Trp53 wild-type (wt) and mutant murine cell lines after $24 \mathrm{~h}$ of treatment with $20 \mu \mathrm{M}$ Nutlin-3 or an equal volume of DMSO. Values represent the mean of $n=3 \pm S E M$.

and may account for why $3 / 6$ TH-MYCN cell lines tested in the present study were either homozygous or heterozygous Trp53 mutant. Certainly, MYCN is known to play a dual role in driving both proliferation and apoptosis, and there are several lines of evidence, including studies using TH-MYCN models, which suggest that $M Y C N$ driven p53-dependent apoptosis is an important mechanism for tumour suppression in neuroblastoma and that $M Y C N$ amplified neuroblastoma cells may circumvent $M Y C N$ driven p53-dependent apoptosis by selecting for cells with aberrations in the p53/MDM2/p14 ${ }^{\mathrm{ARF}}$ pathway, as has been observed for MYCC-driven lymphoma (3,19,26-29). Specifically, as previously demonstrated, tumours formed with greater penetrance and reduced latency in TH-MYCN mice heterozygous for an inactivated germline p53 allele (27). The analysis of human neuroblastoma cell lines reported to date with aberrations in the $\mathrm{p} 53 / \mathrm{MDM} 2 / \mathrm{p} 14^{\mathrm{ARF}}$ pathway demonstrates that $31 / 40$ (78\%) are $M Y C N$-amplified (19). More recently, a study of the role of $\mathrm{p} 53$ function in neuroblastoma pathogenesis using TH-MYCN murine models observed that loss of p53 function led to reduced survival (30).

Nutlin-3 is a potent selective inhibitor of the MDM2p53 interaction (31), previously shown to be highly effective against TP53 wt neuroblastoma cell lines, inducing cell cycle arrest and/or apoptosis, and used to functionally screen large neuroblastoma cell line panels for p53 pathway aberrations $(23,24,32)$. In this study, we found that in all cell lines tested, the presence of a mutation was consistent with high basal levels of p53 and aberrant p53 signalling in response to
Nutlin-3 and IR, and failure to growth arrest in response to Nutlin-3. Consistent with the mechanisms of action of MDM2 inhibitors and existing data from human neuroblastoma cell lines, overall, Nutlin-3 was found to induce cell cycle arrest and/or apoptosis of Trp53 wt control and TH-MYCN murine cell lines $(23,24)$. Of note, in the current study, in response to Nutlin-3 and IR, although there was no induction of p53, an increase in both Mdm2 and $\mathrm{p} 21^{\mathrm{WAF} 1}$ expression was observed in heterozygously mutant $282^{M Y C N+/}$ cells, suggesting there is some residual p53 function from the remaining wt allele (33); however this did not lead to growth arrest or apoptosis in response to Nutlin-3.

MDM2 inhibitors are currently under preclinical and clinical development as a novel therapeutic, both alone and in combination, for human malignancies including neuroblastoma. Of particular interest in view of the latter, data from the present study demonstrated that in comparison to human TP53 wt neuroblastoma cells, murine control $\left(\mathrm{MEF}^{\text {PARP-/ }}\right)$ and TH-MYCN cell lines were significantly less sensitive to MI-63 and RG7388 induced growth inhibition. Although human and murine MDM2 show a high degree of amino acid sequence homology, with only 2 non-identical amino acids within the p53 binding domain (34), these subtle differences could account for a weaker binding affinity to murine Mdm2 which is believed to contribute to the increased resistance and higher $\mathrm{GI}_{50}$ concentrations of murine cells to some MDM2 inhibitors that have been designed with high potency against human MDM2 (35). In support of this, the present 
Table II. Summary of 48-h GI 50 values for MDM2 antagonists in human and murine cells.

\begin{tabular}{|c|c|c|c|c|c|}
\hline \multirow[b]{2}{*}{ Cell line } & \multirow[b]{2}{*}{$48 \mathrm{~h}$} & \multicolumn{4}{|c|}{ Antagonist $(\mu \mathrm{M})$} \\
\hline & & Nutlin-3 & NDD0005 & MI-63 & RG7388 \\
\hline SHSY5Y & $\mathrm{GI}_{50}$ & $1.95 \pm 0.56$ & $1.93 \pm 0.69$ & $0.78 \pm 0.16$ & $0.11 \pm 0.05$ \\
\hline NGP & $\mathrm{GI}_{50}$ & $2.51 \pm 0.3$ & $2.78 \pm 0.02$ & $1.06 \pm 0.12$ & $0.14 \pm 0.03$ \\
\hline $\mathrm{MEF}^{P A R P-/-}$ & $\begin{array}{l}\mathrm{GI}_{50} \\
\text { Rel Fold/P-value vs. SHSY5Y } \\
\text { Rel Fold/P-value vs. NGP }\end{array}$ & $\begin{array}{c}7.10 \pm 0.38 \\
3.6 /^{\mathrm{b}} \\
2.8 /^{\mathrm{b}}\end{array}$ & $\begin{array}{c}6.98 \pm 0.06 \\
3.6 /^{\mathrm{b}} \\
2.5 /^{\mathrm{c}}\end{array}$ & $\begin{array}{c}12.05 \pm 0.63 \\
15.4 /^{\mathrm{d}} \\
11.3 /^{\mathrm{c}}\end{array}$ & $\begin{array}{c}1.61 \pm 0.11 \\
15.0 /^{\mathrm{d}} \\
11.9 /^{\mathrm{c}}\end{array}$ \\
\hline NIH3T3 & $\begin{array}{l}\mathrm{GI}_{50} \\
\text { Rel Fold/P-value vs. SHSY5Y } \\
\text { Rel Fold/P-value vs. NGP }\end{array}$ & $\begin{array}{c}14.1 \pm 2.2 \\
7.4 /^{\mathrm{b}} \\
5.6 /{ }^{\mathrm{b}}\end{array}$ & ND & $\mathrm{ND}$ & ND \\
\hline $\mathrm{NHO} 2 \mathrm{~A}$ & $\begin{array}{l}\mathrm{GI}_{50} \\
\text { Rel Fold/P-value vs. SHSY5Y } \\
\text { Rel Fold/P-value vs. NGP }\end{array}$ & $\begin{array}{c}41.4 \pm 2.7 \\
21.8 /^{\mathrm{d}} \\
16.5 /^{\mathrm{d}}\end{array}$ & ND & ND & ND \\
\hline $282^{M Y C N+/-}$ & $\begin{array}{l}\mathrm{GI}_{50} \\
\text { Rel Fold/P-value vs. SHSY5Y } \\
\text { Rel Fold/P-value vs. NGP }\end{array}$ & $\begin{array}{c}35.3 \pm 1.8 \\
18.6 /^{\mathrm{d}} \\
14.1 /^{\mathrm{d}}\end{array}$ & ND & ND & ND \\
\hline $844^{M Y C N+/+}$ & $\begin{array}{l}\mathrm{GI}_{50} \\
\text { Rel Fold/P-value vs. SHSY5Y } \\
\text { Rel Fold/P-value vs. NGP }\end{array}$ & $\begin{array}{c}36.5 \pm 1.4 \\
19.2 /^{\mathrm{d}} \\
14.5 /^{\mathrm{d}}\end{array}$ & ND & ND & ND \\
\hline $3261^{M Y C N+/+}$ & $\begin{array}{l}\mathrm{GI}_{50} \\
\text { Rel Fold/P-value vs. SHSY5Y } \\
\text { Rel Fold/P-value vs. NGP }\end{array}$ & $\begin{array}{c}3.53 \pm 0.54 \\
1.8 / \mathrm{ns} \\
1.4 / \mathrm{ns}\end{array}$ & $\begin{array}{c}2.38 \pm 0.39 \\
1.2 / \mathrm{ns} \\
0.9 / \mathrm{ns}\end{array}$ & $\begin{array}{c}3.71 \pm 0.3 \\
4.7 /^{\mathrm{c}} \\
3.5 /^{\mathrm{b}}\end{array}$ & $\begin{array}{c}6.36 \pm 1.65 \\
59.1 /^{\mathrm{b}} \\
47.0 /^{\mathrm{a}}\end{array}$ \\
\hline $3394^{M Y C N+/+}$ & $\begin{array}{l}\mathrm{GI}_{50} \\
\text { Rel Fold/P-value vs. SHSY5Y } \\
\text { Rel Fold/P-value vs. NGP }\end{array}$ & $\begin{array}{c}3.09 \pm 0.19 \\
1.6 / \mathrm{ns} \\
1.2 / \mathrm{ns}\end{array}$ & $\begin{array}{c}1.57 \pm 0.63 \\
0.8 / \mathrm{ns} \\
0.6 / \mathrm{ns}\end{array}$ & $\begin{array}{c}4.0 \pm 0.41 \\
5.1 /^{\mathrm{c}} \\
3.8 /^{\mathrm{b}}\end{array}$ & $\begin{array}{c}1.84 \pm 0.50 \\
17.1 / /^{\mathrm{b}} \\
13.6 /^{\mathrm{a}}\end{array}$ \\
\hline $3399^{M Y C N+/+}$ & $\begin{array}{l}\mathrm{GI}_{50} \\
\text { Rel Fold/P-value vs. SHSY5Y } \\
\text { Rel Fold/P-value vs. NGP }\end{array}$ & $\begin{array}{c}4.3 \pm 1.2 \\
2.2 / \mathrm{ns} \\
1.7 / \mathrm{ns}\end{array}$ & $\begin{array}{c}1.58 \pm 0.65 \\
0.8 / \mathrm{ns} \\
0.6 / \mathrm{ns}\end{array}$ & $\begin{array}{c}3.94 \pm 0.58 \\
5 /^{\mathrm{b}} \\
3.7 /^{\mathrm{b}}\end{array}$ & $\begin{array}{c}3.49 \pm 0.37 \\
32.4 /^{\mathrm{c}} \\
25.8 /^{\mathrm{b}}\end{array}$ \\
\hline
\end{tabular}

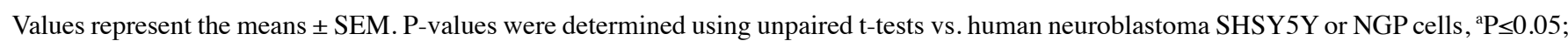
${ }^{\mathrm{b}} \mathrm{P} \leq 0.01 ;{ }^{\mathrm{c}} \mathrm{P} \leq 0.001 ;{ }^{\mathrm{d}} \mathrm{P} \leq 0.0001$; ns, not statistically significant. Rel Fold, fold change relative to the $\mathrm{GI}_{50}$ value of $\mathrm{SHSY} \mathrm{Y}$ cells and the GI ${ }_{50}$ value of NGP cells; vs., versus; ND, not determined.

data showed that the more potent the MDM2 inhibitor was against human neuroblastoma cells, the less sensitive the murine cells were, and the greater the fold difference between $\mathrm{GI}_{50}$ values of Trp53 wt murine cells vs. TP53 wt human cells. These observations are consistent with the inter-species selectivity of spiro-oxindole-based MDM2 inhibitors (36) and dihydroisoquinolinone NVP-CGM097 (37), but not pyrazolopyrrolidinone NVP-HDM201 $(38,39)$, and should be taken into account when designing studies of MDM2 inhibitors either alone or in combination using either preclinical transgenic or human tumour xenograft models as p53-dependent normal tissue toxicity will not be adequately modelled.

Currently, murine neuroblastoma models include genetically engineered mouse models, syngeneic models, and subcutaneous, orthotopic, pseudometastatic and patient-derived xenografts $(3,40-43)$. All models have associated advantages and disadvantages, and it is likely that the most comprehensive preclinical assessment of efficacy will include a combination of existing models. Several of the models predominantly use immunocompromised mice and thus are unsuitable for assessment of immunotherapies, which are emerging as effective targeted therapies in patients with neuroblastoma. To overcome this, cell lines established from the TH-MYCN transgenic model/or other murine neuroblastoma cell lines can be used to generate orthotopic or pseudometastatic syngeneic models of neuroblastoma in an immunocompetent background $(7,8)$. For this, the genetic and functional characterisation of murine cell lines, including Trp53 status and pathway function, are very important and highly warranted, as existing data are limited.

In conclusion, the Trp53 wt and mutant TH-MYCN cell lines characterised in this study can be used in syngeneic models of neuroblastoma, the former to test p53-dependent therapies in combination with immunotherapies, such as anti$\mathrm{GD}_{2}$ antibody, and the latter as models of immunocompetent, chemoresistant relapsed neuroblastoma in which aberrations in the p53 pathway are more common (14-16). 


\section{Acknowledgements}

This study was supported by The Dubois Child Cancer Fund, SPARKS, the North of England Children's Cancer Research Fund (NECCRF), Neuroblastoma UK and Niamh's Next Step. We would like to thank Professor Michelle Haber for the NHO2A cell line and tumour DNA, Dr Gilbert de Murcia for providing

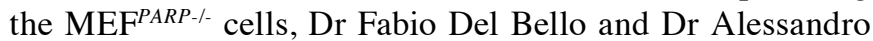
Piergentili for providing MI-63, Dr Steven Middleton (Hoffmann-La Roche, Nutley, NJ, USA) for providing RG7388, and Dr Anna Watson, Dr Karen Haggerty and Dr Ian Hardcastle (Newcastle University) for synthesising NDD0005. We disclose that Dr L. Chen and Professor D.A. Tweddle are part of an international collaborative research consortium with Hoffmann-La Roche Ltd. Professor J. Lunec is a collaborative co-investigator of the CRUK funded Drug Discovery Programme at Newcastle University which developed NDD0005. Newcastle University, Cancer Research Technology and Astex Pharmaceuticals Inc. are part of an alliance agreement since 2012 .

\section{Competing interests}

The authors declare that they have no competing interests.

\section{References}

1. Cohn SL and Tweddle DA: MYCN amplification remains prognostically strong 20 years after its 'clinical debut'. Eur J Cancer 40: 2639-2642, 2004.

2. Weiss WA, Aldape K, Mohapatra G, Feuerstein BG and Bishop JM: Targeted expression of MYCN causes neuroblastoma in transgenic mice. EMBO J 16: 2985-2995, 1997.

3. Chesler L and Weiss WA: Genetically engineered murine models - contribution to our understanding of the genetics, molecular pathology and therapeutic targeting of neuroblastoma. Semin Cancer Biol 21: 245-255, 2011.

4. Rasmuson A, Segerström L, Nethander M, Finnman J, Elfman LH, Javanmardi N, Nilsson S, Johnsen JI, Martinsson T and Kogner P: Tumor development, growth characteristics and spectrum of genetic aberrations in the TH-MYCN mouse model of neuroblastoma. PLoS One 7: e51297, 2012.

5. Cheng AJ, Cheng NC, Ford J, Smith J, Murray JE, Flemming C, Lastowska M, Jackson MS, Hackett CS, Weiss WA, et al: Cell lines from MYCN transgenic murine tumours reflect the molecular and biological characteristics of human neuroblastoma. Eur J Cancer 43: 1467-1475, 2007.

6. Lehembre F and Regenass U: Metastatic disease: A drug discovery perspective. Semin Cancer Biol 22: 261-271, 2012.

7. Stauffer JK, Orentas RJ, Lincoln E, Khan T, Salcedo R, Hixon JA, Back TC, Wei JS, Patidar R, Song Y, et al: High-throughput molecular and histopathologic profiling of tumor tissue in a novel transplantable model of murine neuroblastoma: New tools for pediatric drug discovery. Cancer Invest 30: 343-363, 2012.

8. Kroesen M, Nierkens S, Ansems M, Wassink M, Orentas RJ, Boon L, den Brok MH, Hoogerbrugge PM and Adema GJ: A transplantable TH-MYCN transgenic tumor model in C57Bl/6 mice for preclinical immunological studies in neuroblastoma. Int J Cancer 134: 1335-1345, 2014.

9. Brown CJ, Lain S, Verma CS, Fersht AR and Lane DP: Awakening guardian angels: drugging the p53 pathway. Nature reviews 9: 862-873, 2009. https://doi.org/10.1038/nrc2763.

10. Carr J, Bell E, Pearson ADJ, Kees UR, Beris H, Lunec J and Tweddle DA: Increased frequency of aberrations in the p53/MDM2/p14(ARF) pathway in neuroblastoma cell lines established at relapse. Cancer Res 66: 2138-2145, 2006.

11. Keshelava N, Zuo JJ, Chen P, Waidyaratne SN, Luna MC, Gomer CJ, Triche TJ and Reynolds CP: Loss of p53 function confers high-level multidrug resistance in neuroblastoma cell lines. Cancer Res 61: 6185-6193, 2001.

12. Levine AJ: p53, the cellular gatekeeper for growth and division. Cell 88: 323-331, 1997.
13. Soussi T and Béroud C: Assessing TP53 status in human tumours to evaluate clinical outcome. Nat Rev Cancer 1: 233-240, 2001.

14. Carr-Wilkinson J, O'Toole K, Wood KM, Challen CC, Baker AG, Board JR, Evans L, Cole M, Cheung NK, Boos J, et al: High Frequency of p53/MDM2/p14 ${ }^{\mathrm{ARF}}$ Pathway Abnormalities in Relapsed Neuroblastoma. Clin Cancer Res 16: 1108-1118, 2010.

15. Tweddle DA, Malcolm AJ, Bown N, Pearson AD and Lunec J: Evidence for the development of p53 mutations after cytotoxic therapy in a neuroblastoma cell line. Cancer Res 61: 8-13, 2001.

16. Padovan-Merhar OM, Raman P, Ostrovnaya I, Kalletla K, Rubnitz KR, Sanford EM, Ali SM, Miller VA, Mossé YP, Granger MP, et al: Enrichment of targetable mutations in the relapsed neuroblastoma genome. PLoS Genet 12: e1006501, 2016.

17. Evageliou NF, Haber M, Vu A, Laetsch TW, Murray J, Gamble LD, Cheng NC, Liu K, Reese M, Corrigan KA, et al: Polyamine antagonist therapies inhibit neuroblastoma initiation and progression. Clin Cancer Res 22: 4391-4404, 2016.

18. de Murcia JM, Niedergang C, Trucco C, Ricoul M, Dutrillaux B, Mark M, Oliver FJ, Masson M, Dierich A, LeMeur M, et al: Requirement of poly(ADP-ribose) polymerase in recovery from DNA damage in mice and in cells. Proc Natl Acad Sci USA 94: 7303-7307, 1997.

19. Chen L and Tweddle DA: p53, SKP2, and DKK3 as MYCN target genes and their potential therapeutic significance. Front Oncol 2: 173, 2012.

20. Chen L, Zhao Y, Halliday GC, Berry P, Rousseau RF, Middleton SA, Nichols GL, Del Bello F, Piergentili A, Newell DR, et al: Structurally diverse MDM2-p53 antagonists act as modulators of MDR-1 function in neuroblastoma. Br J Cancer 111: 716-725, 2014.

21. Chen L, Rousseau RF, Middleton SA, Nichols GL, Newell DR, Lunec $J$ and Tweddle DA: Pre-clinical evaluation of the MDM2-p53 antagonist RG7388 alone and in combination with chemotherapy in neuroblastoma. Oncotarget 6: 10207-10221, 2015.

22. Valenzuela MT, Guerrero R, Núñez MI, Ruiz De Almodóvar JM, Sarker M, de Murcia G and Oliver FJ: PARP-1 modifies the effectiveness of p53-mediated DNA damage response. Oncogene 21: 1108-1116, 2002.

23. Gamble LD, Kees UR, Tweddle DA and Lunec J: MYCN sensitizes neuroblastoma to the MDM2-p53 antagonists Nutlin-3 and MI-63. Oncogene 31: 752-763, 2012.

24. Van Maerken T, Rihani A, Dreidax D, De Clercq S, Yigit N, Marine JC, Westermann F, De Paepe A, Vandesompele J and Speleman F: Functional analysis of the p53 pathway in neuroblastoma cells using the small-molecule MDM2 antagonist nutlin-3. Mol Cancer Ther 10: 983-993, 2011.

25. Mazanek P, Dam V, Morgan BT, Liu X, Pawar N and Hogarty MD: Assessment of p19/ARF-MDM-p53 and RAS pathways for alterations in neuroblastomas arising in the transgenic TH-MYCN mouse model. In: Advances in Neuroblastoma Research June 16-19th 2004, Genoa, Italy, 2004.

26. Chen L, Iraci N, Gherardi S, Gamble LD, Wood KM, Perini G, Lunec J and Tweddle DA: p53 is a direct transcriptional target of MYCN in neuroblastoma. Cancer Res 70: 1377-1388, 2010.

27. Chesler L, Goldenberg DD, Collins R, Grimmer M, Kim GE, Tihan T, Nguyen K, Yakovenko S, Matthay K and Weiss WA: Chemotherapy-induced apoptosis in a transgenic model of neuroblastoma proceeds through p53 induction. Neoplasia 10: 1268-1274, 2008.

28. Chen Z, Lin Y, Barbieri E, Burlingame S, Hicks J, Ludwig A and Shohet JM: Mdm2 deficiency suppresses MYCN-Driven neuroblastoma tumorigenesis in vivo. Neoplasia 11: 753-762, 2009.

29. Eischen CM, Weber JD, Roussel MF, Sherr CJ and Cleveland JL: Disruption of the ARF-Mdm2-p53 tumor suppressor pathway in Myc-induced lymphomagenesis. Genes Dev 13: 2658-2669, 1999.

30. Yogev O, Barker K, Sikka A, Almeida GS, Hallsworth A, Smith LM, Jamin Y, Ruddle R, Koers A, Webber HT, et al: p53 loss in MYC-driven neuroblastoma leads to metabolic adaptations supporting radioresistance. Cancer Res 76: 3025-3035, 2016.

31. Vassilev LT, Vu BT, Graves B, Carvajal D, Podlaski F, Filipovic Z, Kong N, Kammlott U, Lukacs C, Klein C, et al: In vivo activation of the p53 pathway by small-molecule antagonists of MDM2. Science 303: 844-848, 2004.

32. Chen L, Malcolm AJ, Wood KM, Cole M, Variend S, Cullinane C, Pearson AD, Lunec J and Tweddle DA: p53 is nuclear and functional in both undifferentiated and differentiated neuroblastoma. Cell Cycle 6: 2685-2696, 2007. 
33. Sun Y, Yi H, Yang Y, Yu Y, Ouyang Y, Yang F, Xiao Z and Chen Z: Functional characterization of $\mathrm{p} 53$ in nasopharyngeal carcinoma by stable shRNA expression. Int J Oncol 34: 1017-1027, 2009.

34. Vassilev LT: Small-molecule antagonists of p53-MDM2 binding: research tools and potential therapeutics. Cell Cycle 3: 419-421, 2004.

35. Khoo KH, Verma CS and Lane DP: Drugging the p53 pathway: Understanding the route to clinical efficacy. Nat Rev Drug Discov 13: 217-236, 2014

36. Delaisi C, Meaux I, Dos-Santos O, Barrière C, Duffieux F, Hoffmann D, Rak A, Wolfrom M, Flèche , Zhou-Liu Q, et al: In vitro characterization of spiro-oxindole-based modulators of the MDM2-p53 interaction and their interspecies selectivity. 103rd Annual Meeting of the American Association for Cancer Research, Mar 31-Apr 4, 2012. Cancer Res 72: Abstract nr 4648, Chicago, IL, 2012.

37. Holzer P, Masuya K, Furet P, Kallen J, Valat-Stachyra T, Ferretti S, Berghausen J, Bouisset-Leonard M, Buschmann N, Pissot-Soldermann C, et al: Discovery of a dihydroisoquinolinone derivative (NVP-CGM097): A highly potent and selective MDM2 inhibitor undergoing phase 1 clinical trials in p53wt tumors. J Med Chem 58: 6348-6358, 2015.
38. Stachyra-Valat T, Baysang F, D'Alessandro A-C, Dirk E, Furet P, Guagnano V, Kallen J, Leder L, Mah R, Masuya K, et al: Abstract 1239: NVP-HDM201: Biochemical and biophysical profile of a novel highly potent and selective PPI inhibitor of p53-Mdm2. Cancer Res 76 (Suppl 14): 1239-1239, 2016.

39. Furet P, Masuya K, Kallen J, Stachyra-Valat T, Ruetz S, Guagnano V,Holzer P, Mah R, Stutz S, Vaupel A, et al: Discovery of a novel class of highly potent inhibitors of the p53-MDM2 interaction by structure-based design starting from a conformational argument. Bioorg Med Chem Lett 26: 4837-4841, 2016.

40. Heukamp LC, Thor T, Schramm A, De Preter K, Kumps C, De Wilde B, Odersky A, Peifer M, Lindner S, Spruessel A, et al: Targeted expression of mutated ALK induces neuroblastoma in transgenic mice. Sci Transl Med 4: 141ra91, 2012.

41. Khanna $\mathrm{C}$ and Hunter $\mathrm{K}$ : Modeling metastasis in vivo. Carcinogenesis 26: 513-523, 2005

42. Khanna C, Jaboin JJ, Drakos E, Tsokos M and Thiele CJ: Biologically relevant orthotopic neuroblastoma xenograft models: Primary adrenal tumor growth and spontaneous distant metastasis. In Vivo 16: 77-85, 2002.

43. Beltinger $\mathrm{C}$ and Debatin KM: Murine models for experimental therapy of pediatric solid tumors with poor prognosis. Int $\mathrm{J}$ Cancer 92: 313-318, 2001 